\title{
INNATE RIGHTS AND JUST RELATIONS ।
}

\author{
Paul Marshall \\ Department of Political Theory \\ Institute for Christian Studies \\ TORONTO
}

\begin{abstract}
Currently the temns rights and human rights are used to refer to two types of entities. One is a kind of legal claim or guarantec given in positive law. The other is a purponed moral claim or interest implicit in the nature of human persons. A peculiar feature of moden discussions of rights is that these diverse things are commonly treated as if they had some necessary relation to one another. In fact, historically and concepttally, they do not and the frequent attenpts to relate them can have inimical results. It can confuse substantive human rights with the promulgation of an individialist view of the person

The defence of human rights (of the types now mentioned in intemational treaties) would be helped by divorcing these from a notion of innate rights and, instead, thderstanding rights as legal guarantees of just political relations.
\end{abstract}

\section{INTRODUCTION}

In the world today and more especially, in South Africa today the most common way of addressing normative issues in politics is by means of theories of rights. Internationally, issues as diverse as trade, medical practice, housing, abortion, court procedure, and relations between the sexes are treated as matters of rights, specifically human rights. In South Africa this list can be reproduced and expanded, and to it can be added especially the urgent resolution of the injustices wrought by racism and the imposition of "separate development". Besides questions of where one can live and work this involves the most basic matter of equality before the law.

Apart from the diffuse spread of a rights vocabulary in policy issues and matters of law, the notion of rights also has become central to many modern theories of politics. Rights pervade the academy as much as the legislature, the court, the negotiating table and the street. Within left and right political thought, theories of rights are commonly

\footnotetext{
${ }^{1}$ This lecture was part of the Stokerlesings of the Department of Philosophy at the PU for CHE in August 1990.
} 
used to explain the source of the state's power, to define the task of the state, and to delineate the state's proper jurisdiction.

One notable feature of these emphases is that human rights are affirmed by people right across the spectra of political opinion and ideology. For this reason they are often, indeed usually, offered as a unifying political creed. However, as I believe that political differences are real, in the sense that they represent real clashes of commitment and interest, then I am inclined to surmise that the claimed, apparent consensus on rights may be somewhat hollow; the same words convey different meaning to different people. When liberals and socialists reach agreement on human rights, have they settled their differences or merely found a new vocabulary in which to argue about their differences?

Another feature of rights is that, even apart from ideological divisions, there is diversity and confusion concerning to what they refer. There are first, second and third generations of rights; there are economic and social rights versus civil and political rights; there are rights understood as goals of state policy versus rights understood as jurisdictional limits on state policy. At least there is agreement that there are substantial disagreements. There is one distinction, however, which most commentators agree is rarely, if ever, confused. This is the distinction between "innate right" and "positive rights". "Innate rights" (alternatively called "natural rights", "subjective rights", "moral rights" or "pre-political rights") are thought to be a type of moral claim, somehow intrinsic to human beings, which entitle people to protection or provisions from states. "Positive rights" are claims guaranteed to people in positive law and capable of sustaining a legal appeal. This distinction is hardly a subtle one and, whatever their diverse views on other matters, most commentators expressly point it out. However, I want to suggest that this distinction is commonly confused or, rather, conflated and that this confusion has been detrimental to the proper understanding and development of human rights. What happens is not that people assume that these two types of rights are identical but that they assume that they necessarily have a close connection. Those who are, very correctly, concerned with the protection of human rights in positive law often, very incorrectly, assume that such protection can only be justified by or, at least, needs to be justified by, or should be justified by some conception of innate rights. Against this view I will maintain that

* no assertion of innate rights is necessary to found a good defence of positive rights;

* it is extremely difficult (if not impossible) to found a view of positive rights on a view of innate rights, and 
* to the degree that innate rights can found a view of positive rights, the results may be quite detrimental to genuine human freedom and flourishing.

Given this situation, and given the importance of a good defence of positive human rights, I will then suggest, briefly, how we might go about founding such rights. In doing so I will not be trying to suggest how to interpret human rights law but, instead, to suggest how such law should be formulated. However, before attending to my own proposals, I will address the relation of innate and positive rights.

\section{INNATE RIGHTS AND POSITIVE RIGIITS}

The distinct nature of these two conceptions can be illustrated from their quite different histories. A history of the substantive protection of human beings in positive law (i.e. positive human rights) would, in a Western setting, survey ancient legal codes, including the Torah, phases of the Greek polis, Roman law, tribal customs, common law, the Petition of Right, grants of religious toleration, the extension of suffrage, international treaties (such as those of The Hague and Geneva as well as explicitly human rights treaties), humanitarian law, and so forth. A second history could concentrate on justifications for such protection. If we limit our survey to the West we could look at Judaism and Christianity, views of justice and right in Greek philosophy, especially Stoicism, Augustine, Thomas and Islamic philosophy would be important. In general it would survey views of natural law, justice and the common good, and would include a large part of the history of political philosophy.

There could be a third history, a subset of the second, that would trace the history of one type of justification for the positive human rights protection given in the first history. This particular mode of justification is a theory that ascribes rights to human beings apart from any consideration of positive law. It holds that human beings, as human beings, already have an entitlement which must be codified in positive law and that rights are thus pre-political. This type of theory includes conceptions of natural rights, innate rights, inherent rights, moral rights and subjective rights. Such a history would show the appearance of an idea of natural right (as distinct from justice, natural duty, natural law, or the right) in discussions by medieval canon lawyers and its further articulation in William of Occam. It would follow the secularisation of this idea through Grotius and its geometrication in Hobbes and Pufendorf. It would explore the idea of a rights based politics through Locke and Kant to contemporaries such as Alan Gewirth, John Rawls, and Ronald Dworkin. 
Perhaps the most ambitious recent attempt to found a notion of innate individual rights is that of Alan Gewirth, who claimed to derive a normative principle of equal human rights solely from a consideration of the nature of human action. By the use of a dialectically necessary method he believed that one would proceed logically from the nature of agency to the claims by each agent to certain rights. By a similar process of logic one could establish that all other human beings have the same rights as oneself (Gewirth, 1981:119-147). Hence he believed that no one could, without selfcontradiction, deny the reality of rights. However, as Alasdair MacIntyre pointed out in his After Virtue, not only is Gewirth's logic faulty, but "... the possession of rights (presupposes) the existence of a socially established set or rules ... They are in no way universal features of the human condition ... those forms of human behaviour which presuppose notions of some ground to entitlement, such as the notion of a right, always have a highly specific and socially local character, and ... the existence of particular types of social institution or practice is a necessary condition for the notion of a claim to the possession of a right being an intelligible type of human performance ... (Macintyre, 1981:65).

It would of course be a little odd that there should be such rights attaching to human beings simply qua human beings in light of the fact "... that there is no expression in any ancient or medieval language correctly translated by our expression 'a right' until near the close of the middle ages ... From this it does not of course follow that there are no natural or human rights; it only follows that no one could have known there were" (op. cit.: $66-67)$.

MacIntyre's view was echoed by A.I. Melden, who sought to demonstrate that there was no knowledge of human rights in the ancient world (Melden, 1988). Many years ago, Condorcet maintained that rights were absent from the legal conceptions of the Romans and the Greeks, and equally from the Jewish, Chinese, and all other civilisations that had come to light.

Apart from the different histories of these conceptions, it is also true that somebody can hold to a view of moral or innate or natural rights without claiming very much about positive rights. John Wycliffe found dominium in the state of nature, but argued on the basis of Christian charity that one must not require any strong claim to property in positive law. His contemporary, Richard Fitzralph, also argued for dominium in the state of nature but maintained that such lordship must now be held by the just, for we have fallen from that which was naturally given. Occam himself, in arguing for a natural right of use, was not trying to establish a right in positive law. Rather, he was arguing for the right of the Francisans not to have legal rights to private (or even 
common) property (McGrade, 1980:149-165). The Franciscans argued that a positive right of property would undercut the natural right of use. They wished to exclude such a right so that, effectively, they would remain in a state of nature. Thomas Aquinas argued for the natural common possession of things but argued for positive individual possession on the grounds that it was more convenient and, while not taught in natural law, was not forbidden by it.

Not only have natural rights been used to justify something other than positive rights or positive human rights, but they have also appeared in opposition to what are regarded as positive human rights. The opposition to welfare rights (and, in the United States, even the idea of a welfare state) has often been based on fairly stringent natural rights grounds. Indeed the notion of a pre-political right held by an individual seems to be at variance with the idea of social or economic rights. While, perhaps, one can conceive of freedom as a right for a natural individual, it is much harder to envisage a prepolitical state which presumes political welfare arrangements.

This point can be made more stringently if we consider the Spanish debates on slavery in the early part of the sixteenth century (Tuck, 1979:48-50). The Spaniards, rather than trying to catch slaves, usually attempted to trade for already enslaved people on the coast of Africa. This activity could, in principle at least, be justified if one could show that it was possible for people to have become slaves on legitimate grounds. In the ensuing arguments about the slave trade, natural rights theories played an important part, but their part was one which tended to justify rather than oppose slavery. Those who held to natural rights views held that rights were like property, indeed that a pre-political right to property was the very epitome of a right. People owned their rights and could dispose of them. As rights were thought to inhere in the human person rather than in the civil order, then a person could legitimately sell them, forfei them, or give them away. Thus a person could become a slave, a person without rights, in a quite legitimate way. Thus certain persons could justly be slaves, and trade in such slaves would be quite acceptable. These were slim grounds indeed, but grounds they were, and they were used. Indeed they were the same grounds as Suarez and Hobbes later used to justify political absolutism in a situation where, purportedly, an entire people, in order to receive protection, had traded away its rights in a social contract.

The principal argument against this confluence of slavery and rights was that of the Dominicans under the influence of a revived Thomism. They, as christianized Aristotelians, were not enamored of natural rights conceptions and placed much stronger limits on what people were free to do. Hence they argued that people were not, in 
general, free to dispose of supposed rights and were, consequently, not free to enslave themselves. Therefore it was unlikely that there could be legitimate slavery and persons could not rightfully be traded as slaves. In this situation arguments against rights were arguments against the slave trade.

Natural rights theories can be equally a foundation for personal and social freedom or a foundation for authoritarianism or totalitarianism. In fact most early modern natural rights theories were justifications for authoritarian states: this is true for Suarez, Grotius and Pufendorf, as well as for Hobbes. The fact that many of the most brutal regimes in the world today proclaim their adherence to human rights is not purely propaganda and bad faith, though it is surely that, but it is also a real facet of the contradictions of contemporary rights theories.

One natural rights theory that, despite its other problems, did manage theoretically to limit the power of government was that of John Locke. Locke, however, managed to do so only by limiting freedom in the first place. He began his Second Treatise on Government by pointing out such limits. He reasserted that Adam did not have dominion over the world (Locke, II.I.I). He affirmed that man's liberty did not extend to his being able to destroy himself, for he was God's property (op. cit. II.II.6). In sum, for Locke, "The state of nature has a law of Nature to govern it, which obliges every one" (op. cit. II.II.6). In Locke's view it was not the case that all obligations rested on the mutual limitations of the reciprocal wills of men expressed in a contract. There were other binding obligations which were prior to the contract. Consequently, in Locke's theory, when mankind entered into a compact to make one "Body Politic" they were not free to erect whatever set of arrangements accorded with their own wills, interests or calculations. "No body can give more Power than he has himself; and he that cannot take away his own Life, cannot give another power over it." (op. cit. IIIV.23). In Locke the limitations on government stemmed from the original limitation on people's own rights in the state of nature. What people did not have themselves they could not transfer to government. The liberties in Locke's civil society stemmed from the limitations that were put on rights and freedoms in the first place. This was in stark contrast to Hobbes, who imputed all power and rights to men in the state of nature and, through the contract, ended up with a government which was the embodiment of all these rights and could do what it willed. In Locke the limitation of natural freedom, natural right, was the very thing that lead to a measure of politicial freedom. 


\section{RIGHTS AND LEGAL RELATIONS}

When we speak of a right we cannot just speak of A's right, but we must also speak of A's right to $B$ and, when we do so, we imply that $C$ should respect this right, and perhaps that $D$ should enforce it. A statement of right specifies a particular type of legal relation between A, B, C, D. It is difficult to see how a relation between many persons in differing circumstances could be found somehow to inhere in one of them (or even to be present in a natural, "pre-political", state at all) (Marshall, 1985:119142). In treating a right as inherent in a person, what appears to have happened is that people have wanted to justify a particular kind of proper legal relation in society. In order to show that the legal relation is normative they argued that it was natural or innate, i.e. that it had some existence prior to the existence of social relations. Hence they "read back" the relation from a positive legal structure into a supposed "natural" condition.

Instead of this process whereby a supposed moral right is then "read forward", "applied", extrapolated contextualized, or specified into a form of positive law, we need to give a much greater place to the actual political/legal formation of rights. This requires at least a three stage process. Such a process is at once more cumbersome than many other rights views and it gives far greater actual creative power to political authorities. I say this by way of explanation, not apology, for such a multistage process is necessary, and is much closed to the actual everyday reality of the formation of positive human rights law in both municipal and international settings. Even those who claim a form of innate rights usually have to follow a procedure similar to the one that I shall try to outline. The three stages are

* the specification of what it is that should be the object of attention in human legislation,

* the determination of the mode of judgement when we are concerned with the relations of more than one, when claims are in real or potential conflict, and

* the determination of the appropriate means of positivizing the determinations which come from the second stage. 


\section{A PROCEDURE FOR SUGGESTING THE CONCERN OF HUMAN RIGHTS LEGISLATION}

While human rights do not inhere in the human person, nevertheless human rights are the rights of human beings and so anthropology has to be a central factor in their discussion. We need to know what features of the human person are of particular concern for rights. There is no shortage of candidates for such concern and this is one of the major areas of controversy in human rights debates. Suggestions offered include agency, autonomy, freedom, will, claims, needs and interests. Each of these suffer from problems. The concepts of agency, autonomy, will and freedom are capable of almost limitless expansion and no such expanded conception seems remotely susceptible to government guarantee. The bare notions of claims suffer from similar problems, for almost anything can and has been claimed. Legal positivization is at the mercy of whatever claims are advanced, or most forcefully advanced. There is also the problem that those who cannot claim, such as babies, may be held to have no rights.

While this subject needs much more discussion, I will, in order to outline my procedure, suggest and assume that the proper focus of human rights legislation should be human need. This reflects, inter alia, the fact that concern for rights is founded in God's grace rather than human merit. However, the criterion of need raises questions of its own. In particular it provokes the question "need for what?" In order to answer this question we need to develop a contextualised view of an appropriate life of and for human beings. I am not suggesting that people should be ordered to live such a life, but I am suggesting that any concept of need must necessarily specify a type of life to which the needs pertain. Otherwise each could demand their own personal definition.

The question of an appropriate human life can be approached in terms of an understanding of human vocation or calling. Each person is called by God to be a servant of others as a neighbour, a citizen, a friend, a co-worker, a wife, husband, parent and/or child. Each person has a legitimate claim to be able to carry out these responsibilities. Hence I would suggest that the what-is-to-be-protected in human rights legislation is the ability of each person to follow his life's vocation, understood as a responsible pattern of life in community in a particular historical circumstance. Such a vocation is not to be demanded by law but is to be the matter of concern in legal rights. Hence the goal of human rights legislation is to protect the legitimate interest and claim that each has in the meeting of their needs so that they may fulfil their vocation in a responsible manner. This may be called a "legitimate claim (See Feinberg, 1973:86f.).

But, of course, what I have suggested as the what-is-to-be-protected of rights will vary 
depending on the situation of others. What we are called to do depends on others and, given a world of scarce resources, what is available for us depends on the calling of others. In this case what may be appropriate to provide/protect for a person will depend on what other legitimate claims are at stake. This provokes the question of how we deal with the relation of different claims rights, especially when what appears appropriate for each cannot be met for all. The response here needs to be in terms of what is appropriate for each one considered together, and this points to the necessity of the criterion of justice (Stone, 1978:995-1024). Justice points to the manner and means of weighing different claims. Claims, in turn, as God-given areas of responsibility and authority, point to the limits of the state's acting and to what it is that needs to be related in a just fashion. Hence the second stage is the just simultaneous interrelation of many legitimate claims.

What I have tried to describe so far is essentially a form of normative political decision making: what are we trying to protect, and how do we decide about competing demands for protection? Now we face the questions of formulating rights in positive law. One of the key features of rights (emphasized by nearly all authors) is that they are basic (sometimes described as fundamental, foundational, inalienable) and should normally win out over other considerations. This is why Ronald Dworkin calls them "trumps". This is a feature with which I have not dealt and so, the conception of rights that I am suggesting may seem frail or relativistic. However, as we have seen from the discussions of innate rights, the foundational nature of rights does not lie in the fact that rights are epistemically or ontologically basic, or that they are the beginning point of a consideration of the nature of a just state. Rather the stress on the basic character of rights is that they are legally and politically important. Legal rights safeguard people from being oppressed by governments pursuing their own policies and goals. Rights provide a limit over which governments cannot trespass, or over which they can only trespass with great difficulty. The purpose of rights is to control governments and so, rights must be more basic than other forms of government activity, including government laws. Hence the essential point is not that rights are basic moral concepts but that they should be part of basic law, i.e. that the law should recognise rights, that the government should be subject to such law so that its policy is consistently and stably directed towards the meeting of positive human rights, and that it is restrained from violating human rights in other aspects of its policy.

There are several ways of seeking to promote such legal safeguards. These include common law guarantees, legal principles, and even the practice of democracy itself. A common practice in the modern world is to place human rights guarantees within a 
constitution so that they are part of the law over the government itself. This produces charters and bills of rights. While such a charter is by no means a panacea, government practice in South Africa suggests that it is a necessity in this country.

\section{CONCLUDING REMARKS}

I have tried very briefly to sketch how we can arrive at an understanding of positive human rights. In the light of this sketch we can say that positive human rights are legal guarantees of the freedoms and the resources which must be protected for each person in the state, which are to be arrived at by a just adjudication of competing legitimate claims in recognition of the responsibility and authority of human persons to pursue their vocation. While no theoretical discussion is, in itself, sufficient basis on which to deal with a practical problem, this discussion does suggest some things relevant to South Africa:

- Whether the claims by certain Calvinists that a concern for human rights is "humanistic" has any validity with respect to a view of innate rights is, in terms of this paper, an open question. However, as a notion of innate rights has no particular connection to a view of positive human rights then such a point is irrelevant to the defense of the latter.

- While a stress on innate rights would not seem to justify "second-generation" economic and social rights, the procedure I have outlined would justify such rights in particular circumstances.

- The formulation of positive human rights needs to be contextual and historically sensitive. While it is always to be guided by principle, it need not and should not be purely formal and the same at all times and all places. Given South Africa's history, human rights legislation here must stress the curtailment of excessive legislative control and executive discretion. It must also have a particular focus on overcoming racism as is suggested, for example, in the African National Congress's recent "Constitutional Guidelines" and, to a lesser extent, in Justice Olivier's Law commission report. 


\section{BIBLIOGRAPIIY}

FEINBERG, JOEL. 1973. Social Philosophy. Englewood Cliffs : Prentice-Hall.

(iEWIRTH, ALAN . 1981. The basis and contents of human rights. (In Pennock, J.R. \& Chapman, J.W eds., Human Rights. New York : New York University Press. p. 119-147.)

LOCKE, JOHN. Two treatises of government. Book II, chapter 1, para. 1 (II.1.1). Ed. by Laslett, P. Cambridge : Cambridge University Press.

MacINTYRE ALASDAIR, 1981. After virtuc. Notre Dame : University of Notrc Dame Press.

MARSHALL, P. 1985. Dooyeweerd's empirical theory of rights. (In MacIntire, C.T. Lanham : University of Press of America. p. 119-142.)

Mc(jRADE, A.S. 1980. Ockham and the birth of individual rights (In Ticrney, B. \& Linchan, P. eds., Authority and power: Studies in Medicval law and government. Cambridge : Cambridge University Press. p. 149-165.)

MELDEN, A.I. 1988. Rights in moral lives. Berkelcy : University of California Press.

STONE, JULIUS. 1978. Justice not equality. Hastings Law Joumal, 29:995-1024.

TUCK, R. 1979. Natural rights theories: Their origin and development. Cambridge : Cambridge University Press. 
